Briefiy clescribed, the method proposed for the determination of gliadin by the polariscope is as follows: Weigh 15.97 grams of flour into a flask and add roo cc. of 70 per cent. alcohol. Shake the flask moderately at intervals of a half hour for two on three hours. Leave the alcohol in contact with the hour for from twelve to eighteen hours, at a temperature of about $20^{\circ} \mathrm{C}$. Filter the alcoholic solution and polarize, using a $220 \mathrm{~mm}$. tube. Multiply the reading on the sugh scale !y 0.2 . Which gives approximately the per cent. of gliadin nitrogen.

The time of extraction with alcohol can be lessened by the use of a shaking machine and then clarifying the solution by centrifugal action. Excessive shaking is to be avoided, otherwise cloudy filtrates are obtained which cannot be polarized. Some flours, particularly soft wheat flours, frequently sive cloudy filtrates. If the alcoholic solutions are kept too lons: they becons? cloudy and cannot be polarized.

The interpretation of results, particularly as to the amount of gliadin which a sample of flour shall contain for good breaclmaking purposes, is a separate feature of the problem of testing wheat and flour for commercial purposes. As yet, only a limited number of gliadin determinations are available, and only tentative standards are possible. In general, it can be said that flour of good quality should contain I 2 per cent. of total proteids $(N \times 6.25)$, or about II per cent. protem ( $N \times 5.7)$, and that from 55 to 65 per cent. should be in the form of gliadin. It is believed that the method as here proposed of determining the gliadin content of flour by means of the polariscope will be found both rapid and accurate, and particularly applicable where large numbers of determinations are to be made.

TNIVERSITY OF MINNESOTA,

MINNEAPOLIS, MINN.

\title{
THE HYDROLYSIS OF MALTOSE AND OF DEXTRIN BY DILUTE ACIDS AND THE DETERIINATION OF STARCH.
}

By William a. Noyes, Gilbert Cranford, Charles H. JUMPER, Fdiak L. Flory, AND ROBERT B. AR NOLD.1

Receiver December 10, 1903 .

The method of determining starch in common use consists in converting the starch into a mixture of maltose and dextrin by

1 The work here described formed the basis for theses which were presented for the degree of Bachelor of Science at the Rose Polytechnic Institute by Mr. Crawford in Igor, by Messrs. Jumper and Flory in 1902, and by Mr. Arnold in I903. 
means of diastase, followed, after filtration, by hydrolysis of this mixture to glucose by means of a dilute acid. The time required for the hydrolysis of maltose has been determined empirically by finding the length of the time necessary to give a product which shows a maximum reduction of Fehling's solution. ${ }^{1}$

So far as we are aware no one has ever determined the rate of hydrolysis for maltose and dextrin under the conditions which obtain in the determination of starch. It appeared to us that a determination of this rate would give valuable information with regard to the length of time required for the hydrolysis. Sigmond ${ }^{2}$ has determined the rate of hydrolysis for maltose at temperatures of $63.7^{\circ}$ to $83.76^{\circ}$, but these determinations have little value for the purpose in question.

In our early experiments Mr. Crawford followed the hydrolysis of maltose by means of the decrease in rotation occasioned by the change from maltose to glucose. Using a Io per cent. solution of maltose, to which Io per cent. by volume of hydrochloric acid (sp. gr. I.I25) was added, and heating on a water-bath for varying times, the following results were obtained:

$\begin{array}{ccccc}\begin{array}{c}\text { Time. } \\ \text { Minutes. }\end{array} & \begin{array}{c}\text { Rotation. } \\ \text { Degrees. } \\ \text { 2I.07 }\end{array} & \begin{array}{c}\text { Maltose. } \\ \text { Per cent. } \\ \text { I00.0 }\end{array} & \begin{array}{c}\text { Giucose. } \\ \text { Per cent. }\end{array} & \text { C. } \\ 0 & 16.7 & 65.2 & 0 & \ldots \ldots \\ 5 & 11.8 & 26.1 & 73.8 & 0.0372 \\ 15 & 9.3 & 6.1 & 93.9 & 0.0427 \\ 30 & 9.0 & 4.0 & 96.0 & 0.0404 \\ 45 & 8.5 & \ldots .0317 \\ 60 & 8.53 & 0 & \ldots & \ldots \ldots \\ \infty \text { (calc.) } & & & & \ldots \\ & & & & \text { Average, } 0.0380\end{array}$

Time for 50 per cent. hydrolysis (calculated), 7.9 minutes.

\begin{tabular}{|c|c|c|c|c|c|}
\hline “ & 90 " & "، & ‘ & “، & 26.2 \\
\hline ، & 99 & ، & ، & ، & 52.6 \\
\hline " & $99.5^{\prime \prime}$ & ، & " & “ & 60.5 \\
\hline
\end{tabular}

In the table the rotation for complete hydrolysis is

$$
21.07 \times 52.7=8.53^{\circ},
$$

assuming $130.2^{\circ}$ as the rotation for maltose containing I molecule of water of crystallization and $52.7^{\circ}$ as the rotation for

1 Meiss1: J. prakt. Chem., [2], 25, 124 (1882).

2 Ztschr. phys. Chem, $27,385$. 
glucose for sodium light. The constant $\mathrm{C}$ is calculated by the usual formula

$$
\mathrm{C}-\therefore=\frac{\mathrm{I}}{t} \log \frac{\mathrm{A}}{\mathrm{A}-x},
$$

in which A represents the change in rotation for complete hydrolysis of the maltose to glucose and $x$ represents the change in rotation which has taken place at a given time. ${ }^{1}$ The time for 5o per cent. hydrolysis is calculated by the formula

$$
t=\frac{\log _{\mathrm{A}} \mathrm{A}-x}{\mathrm{C}}
$$

in which $A=100$ and $x$ is the per cent. assumed as hydrolyzed.

In most of the work, more dilute solutions were used and the determinations were made with Fehling's solution. A large number of experiments were carried through, which, in the end, are treated as preliminary, because they were superseded by others, in which the methods employed were more satisfactory. While probably three-fourths of our time was spent uipon experiments of this nature, and many of these experiments gave results similar to those recorded below, we shall make no attempt to describe them, nor shall we separate, in the further description, the work of individuals.

Effect of Heating Glucose with Hydrochloric Acid.-To a solution of pure glucose containing approximately 0.5 per cent., Io per cent. of hydrochloric acid (sp. gr. I.I25) ${ }^{2}$ by volume was added; different portions were heated on a water-bath for varying times, with care that the volume was unchanged, then neutralized and the glucose was determined by Fehling's solution. The results given were obtained by three different observers at considerable intervals of time.

$$
\begin{aligned}
& \text { Solution of glucose not heated....... } 0.1903 \quad 0.1905 \quad 0.2016
\end{aligned}
$$

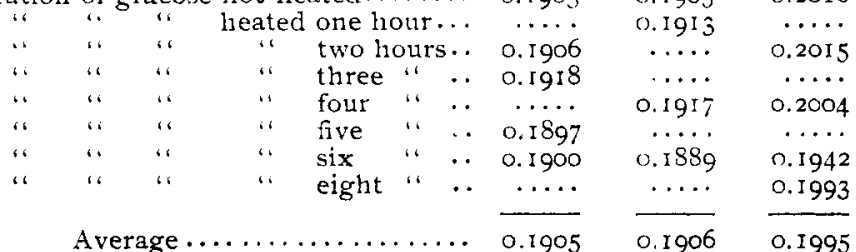

"See Ostwald: "Lehrbuch d. allg. Chem.," II, 2, p. 20 r.

2 This corresponds to about 2.5 per cent. hydrochloric acid in the solution heated and is the amount used in standard methods of determining starch. 
With a single exception, which is probably accidental, the results vary scarcely more than the probable error of the determination. It is evident that the reducing power of the glucose solution, as determined by Fehling's solution, is not appreciably altered by heating with acid. It does not follow that the glucose is not altered. Indeed, some alteration is indicated by the darkening of the solutions on prolonged heating. These results do not altogether agree with those of Meiss1, ${ }^{1}$ who found a loss in reducing power of about 2 per cent. when glucose is heated with 3 per cent. hydrochloric acid for three hours. Winston ${ }^{2}$ found no change in reducing power when glucose was heated with 2 per cent. hydrochloric acid for three hours, but a loss of 3.15 per cent. in eleven hours and of 5.41 per cent. in seventeen hours.

Effect of an Excess of Alkali in Neutralizing a Glucose Solution.-The fact that glucose is extremely sensitive to alkalies is well known and could be predicted from its aldehyde nature, but the important bearing of the fact on the neutralization of glucose solutions, which is incidental to the determination of starch, has not, we think, been sufficiently emphasized. A solution of glucose was prepared and, after adding to different portions of it water, or water and acid, or water, acid and sodium hydroxide in such amounts that the concentration for glucose was identical throughout each series, determinations were made with Fehling's solution. The following amounts of cupric oxide were found:

Original solution with water $\ldots \ldots \ldots \ldots \ldots \ldots\left\{\begin{array}{ccc}\text { I. } & \text { II. } & \text { III. } \\ 0.2 \mathrm{I} 54 & 0.2 \mathrm{I} 68 & \ldots \ldots \\ 0.2 \mathrm{I} 36 & 0.2 \mathrm{I} 70 & \ldots \ldots\end{array}\right.$

Solution with acid only........................... $0.2 \mathrm{I} 48$

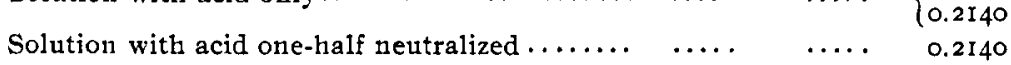

Acid four-fifths neutralized .............. $\left\{\begin{array}{lll}0.2128 & 0.2158 & 0.2156\end{array}\right.$

Acid exactly neutralized $\ldots \ldots \ldots \ldots \ldots \ldots \ldots\left\{\begin{array}{lll}0.2 \mathrm{I} 36 & 0.2168 & \ldots \ldots \\ 0.2094 & 0.2132 & 0.2110\end{array}\right.$

Acid six-fifths neutralized $\ldots \ldots \ldots \ldots \ldots \ldots \ldots\left\{\begin{array}{lll}0.2150 & 0.2116 & \ldots \ldots \\ 0.2102 & 0.1956 & \ldots \ldots \\ 0.2114 & 0.1986 & \ldots \ldots\end{array}\right.$

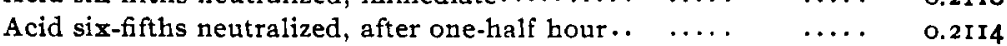

Acid six-fifths neutralized, after two hours ... ... $\ldots . .60 .2072$

It is evident that alkaline and even neutral solutions give low

1 J. prakt. Chem., [2], 25, 127 (1882).

$2 \mathrm{~J}$. Anal. Chem., 2, 152 (1888). 
results in comparison with solutions of pure glucose, while slightly acid solutions give nearly correct results. In all the later work, accordingly, we have been careful, in neutralizing, to leave the solution somewhat acid. It is very important, also, that the solution should be cold before it is neutralized.

Copper Oxide Factor for Glucose.-In determining the rate of hydrolysis of maltose and dextrin by means of Fehling's solution it was necessary to use a method of precipitation which would apply equally to maltose and to glucose. Allihn's ${ }^{1}$ method is not suitable, as he directs to boil two minutes for glucose and four minutes for maltose. Defren's" method uses the same length of time for all sugars and was selected as most suitable for our purpose. We carrifd out the method as follows: I $5 \mathrm{cc}$. of copper sulphate solution ( 69.278 grams to the liter), I $5 \mathrm{cc}$. of the alkaline tartrate solution ( 356 grams Rochelle salt and Ioo grams sodium hydroxide to the liter), and $50 \mathrm{cc}$. of water were put into a $300 \mathrm{cc}$. Erlenmeyer flask. The flask, covered with a watch-glass, was placed on a water-bath for five minutes, $25 \mathrm{cc}$. of the sugar solution ( 0.5 per cent. or less) were then added from a pipette and the heating was continued for fifteen minutes. The solution was then filtered on asbestos, supported on a platinum disk in a Soxhlet tube of hard glass. The asbestos was purified as directed by Defren. After filtration, the tube was dried in an air-bath at $150^{\circ}-175^{\circ}$. It was then attached to a Bunsen pump, heated with a burner and air aspirated through it till the oxidation to cupric oxide was complete.

To determine the copper oxide factor we used a pure glucose (Kahlbaum's), which we recrystallized from alcohol. ${ }^{3}$ It melted at $144^{\circ}-146^{\circ}$.

$\begin{array}{cccc}\text { Glucose. } & \begin{array}{c}\text { Copper oxide } \\ (\text { CuO })\end{array} & \begin{array}{c}\text { Copper oxide } \\ \text { per gram glucose. }\end{array} & \begin{array}{c}\text { Glucose } \\ \text { equivalent. } \\ 0.0405\end{array} \\ 0.1044 & 2.578 & 0.3879 \\ 0.0623 & 0.155^{8} & 2.501 & 0.3999 \\ 0.0824 & 0.2014 & 2.444 & 0.4091 \\ 0.0937 & 0.2255 & 2.407 & 0.4155 \\ 0.1008 & 0.2416 & 2.397 & 0.4172 \\ 0.1117 & 0.2627 & 2.352 & 0.4252\end{array}$

\footnotetext{
1 See Wiley's "Principles and Practice of Agricultural Antalysis," Vol, III, pp. 155 and 165

2 This Journal, 18,75 s.

3 I,evy: "Anleit. z. Darst. org. Prep.," p. so.
} 
These values differ very considerably from those of Defren, ${ }^{1}$ and differ also, though not as greatly, from those recently obtained by Dr. Rolfe. ${ }^{2}$ They emphasize again the necessity for each worker to check his results with Fehling's solution by making determinations with pure glucose.

Hydrolysis of Maltose.-The rate of hydrolysis for maltose was determined as follows: One gram of maltose, containing I molecule of water of crystallization, was dissolved in water and the volume made up to $200 \mathrm{cc}$. Twenty cc. of 25 per cent. hydrochloric acid were then added and portions of $25 \mathrm{cc}$. each were placed in several test-tubes. The latter were weighed and then placed in a boiling water-bath. It was estimated that three minutes were required for the solution to acquire the temperature of the bath. At intervals, a tube was removed from the bath, cooled, brought back to its original weight by the addition of water, if necessary, neutralized and the amount of copper oxide obtained by adding $25 \mathrm{cc}$. to Fehling's solution was determined in the manner described above.

The method of calculation will be apparent from the following table:

Series I. -0.5 Per Cent. Solution.

$\begin{array}{ccccc}\begin{array}{c}\text { Time. } \\ \text { Minutes. }\end{array} & \text { Copper oxide } & \begin{array}{c}\text { Per Cent. } \\ \text { hydrolyzed. }\end{array} & \mathbf{K} . & \begin{array}{c}\text { Per cent. of } \\ \text { total copper oxide. }\end{array} \\ 0 & 0.14 \mathrm{I} 8 & \ldots \ldots & \ldots \ldots & \mathbf{5 7 . 4 9} \\ 5 & 0.1940 & 49.7 \mathrm{I} & 0.0597 & 78.6 \mathrm{I} \\ \mathrm{I5} & 0.2256 & 79.8 \mathrm{I} & 0.0463 & 91.4 \mathrm{I} \\ 30 & 0.2376 & 9 \mathrm{I} .24 & 0.0353 & 96.27 \\ 60 & 0.2440 & 97.33 & 0.0262 & 98.87 \\ \text { I20 } & 0.2475 & 100.66 & \ldots \ldots & 100.28 \\ \text { I80 } & 0.2448 & 98.09 & \ldots \ldots & 98.92 \\ \infty \text { (calc.) } & 0.2468 & 100.00 & \ldots \ldots & 100 . \infty\end{array}$

It should be noticed in this and the following tables that the per cent. of total copper oxide and not the per cent. of hydrolysis is the measure of the accuracy which would be obtained in an actual determination of starch. The result at two hours in this series is doubtless misleading, as an indication of complete hydrolysis was not obtained in any other experiment.

1 Loc. cit.

2 Private communication. See also this Journal, 25, 1008 
Series II. - 0.5 Per Cent. Solution.

Time. I. II. Average per cent.

$\begin{array}{cccccc}\text { Minutes. } & \text { Copper oxide. } & \text { Copper oxide. } & \text { hydrolyzed. Average K. total copper ox } \\ 0 & 0.1405 & 0.1405 & \ldots . & \ldots . . & 57.35 \\ 6 & 0.2018 & 0.1942 & 55.02 & 0.0580 & 76.73 \\ \text { II } & 0.2132 & 0.2136 & 69.78 & 0.0473 & 87.10 \\ \text { I6 } & 0.2208 & 0.2240 & 78.37 & 0.0416 & 90.77 \\ \text { 2I } & 0.2298 & 0.2280 & 84.97 & 0.0393 & 93.43 \\ \text { 3I } & 0.2370 & \ldots \ldots & 92.34 & 0.0373 & 96.73 \\ 6 \text { I } & 0.2428 & 0.2386 & 95.88 & 0.0238 & 98.24 \\ \text { Hours. } & & & & & \\ 2 & \ldots \ldots & 0.2396 & 94.84 & \ldots \ldots & 97.80 \\ 4 & \ldots \ldots & 0.2398 & 95.02 & \ldots \ldots & 97.84 \\ 6 & \ldots \ldots & 0.2410 & 96.17 & \ldots \ldots & 98.37 \\ \infty \text { (calc. }) & 0.2450 & 0.2450 & 100.00 & \ldots \ldots & 100.00\end{array}$

SERIES III.-2 PeR CFNT. SOlution.

Time. I. II. Average percent. Average per cent. Minutes. Copper oxide. Copper oxide. hydrolyzed. Average K. total copper oxide.

$\begin{array}{rrrrrr}0 & 0.1268 & 0.1268 & 0.00 & \ldots \ldots & 57.74 \\ 5 & 0.1580 & 0.1610 & 35.23 & 0.0378 & 71.72 \\ 10 & 0.1806 & 0.1822 & 58.83 & 0.0386 & 82.62 \\ 15 & 0.1960 & 0.1954 & 74.25 & 0.0393 & 89.11 \\ 20 & 0.2050 & 0.2070 & 85.34 & 0.0418 & 93.78 \\ 30 & 0.2120 & 0.2118 & 91.70 & 0.0360 & 96.49 \\ \text { 60 } & 0.2174 & 0.2162 & 96.98 & 0.0255 & 98.72 \\ \text { Hours. } & \ldots \ldots & 0.2178 & 98.06 & \ldots \ldots & 99.18 \\ 2 & \ldots \ldots & 0.2162 & 96.33 & \ldots \ldots & 98.45 \\ 4 & \ldots \ldots & 0.2196 & 100.00 & \ldots \ldots & 100.00\end{array}$

Series IV. 4 Per Cent. Solution.

$\begin{array}{ccccc}\begin{array}{c}\text { Time. } \\ \text { Minutes. }\end{array} & \text { Copper oxide. } & \begin{array}{c}\text { Per cent. } \\ \text { hydrolyzed. }\end{array} & \text { K. } & \begin{array}{c}\text { Per cent. of } \\ \text { total copper oxide. }\end{array} \\ 0 & 0.1268 & 0.00 & \ldots \ldots & 57.74 \\ 5 & 0.166 & 42.89 & 0.0487 & 75.85 \\ 10 & 0.1892 & 67.24 & 0.0485 & 86.16 \\ 15 & 0.1990 & 77.80 & 0.0436 & 90.62 \\ 20 & 0.2074 & 86.85 & 0.044 \mathrm{I} & 94.44 \\ 30 & 0.2154 & 95.47 & 0.0448 & 98.09 \\ 60 & 0.2176 & 97.84 & 0.0278 & 99.09 \\ \text { Hours. } & & & & \\ 2 & 0.2150 & 95.04 & \ldots \ldots & 97.86 \\ 4 & 0.2154 & 95.47 & \ldots \ldots & 98.09 \\ \infty \text { (calc.) } & 0.2196 & 100.00 & \ldots \ldots & 100.00\end{array}$

An examination of these results shows very clearly that the reaction does not proceed to its conclusion as a normal mass reaction. For from twenty to thirty minutes the values of $\mathrm{K}$ do not diverge very widely from the average except for the five- and 
six-minute periods and the divergence in those cases may be partly occasioned by the uncertainty in regard to the time required for the solutions to reach the temperature of the bath. At the rate indicated by this constant, 99.5 per cent., or more (see p. 268), of the maltose should be hydrolyzed at the end of one hour. The actual hydrolysis in sixty minutes is found to be from 95.88 to 97.84 per cent. After one hour the amount of copper oxide found decreases in almost all cases. As it is shown above that the reducing power of glucose decreases very slowly indeed, if at all, on heating with acid of this strength, it would seem that a portion of the maltose is converted into some other substance than glucose.

In any case, it seemed evident, from a practical standpoint, that a complete hydrolysis cannot be obtained by this method of heating and that no advantage is gained by prolonging the heating beyond one hour.

A few experiments were made with a ro per cent. solution boiled over a free flame with a return condenser. The constant was approximately 0.06 , which would correspond to a hydrolysis of 99.5 per cent. in thirty-eight minutes.

Experiments were also made with an acid $1 / 5$ as strong. This gave, on the water-bath, a constant of approximately 0.006 , and over the free flame, a constant of approximately 0.008 , which would correspond, respectively, to 380 minutes and 260 minutes for a hydrolysis of 99.5 per cent. What degree of hydrolysis could actually be reached at the end of such a period was not determined.

Hydrolysis of Maltose at $I 10.8^{\circ}$.-A number of determinations of the rate of hydrolysis of maltose at a temperature of $110.8^{\circ}$ were made by placing solutions, prepared as before, in sealed tubes and heating these by suspending them in the vapor of boiling toluene. The concentration of the hydrochloric acid was the same as in the cases already given, viz., $20 \mathrm{cc}$. of hydrochloric acid of 25 per cent. were added to $200 \mathrm{cc}$. of the maltose solution.

\begin{tabular}{|c|c|c|c|c|}
\hline $\begin{array}{c}\text { Time. } \\
\text { Minutes. }\end{array}$ & $\begin{array}{l}\text { Copper } \\
\text { oxide. }\end{array}$ & $\begin{array}{l}\text { ER CENT. } \\
\text { Per cent. } \\
\text { hydrolyzed. }\end{array}$ & N. & $\begin{array}{l}\text { Per cent. of total } \\
\text { copper oxide. }\end{array}$ \\
\hline 0 & o.1405 & $\cdots$ & $\ldots \ldots$ & 57.35 \\
\hline I5 & $0.24 I 4$ & 96.56 & 0.0975 & 98.53 \\
\hline 30 & 0.2434 & 98.47 & 0.0606 & 99.34 \\
\hline calc.) & $0.245^{\circ}$ & $100 . \infty 0$ & $\ldots \ldots$ & $100 . \infty 0$ \\
\hline
\end{tabular}


2 Per Cent. Solution.

\begin{tabular}{|c|c|c|c|c|}
\hline $\begin{array}{l}\text { Time. } \\
\text { Minutes. }\end{array}$ & $\begin{array}{l}\text { Coppet } \\
\text { oxide. }\end{array}$ & $\begin{array}{l}\text { Per cent. } \\
\text { hydrolyzed. }\end{array}$ & $\mathrm{k}$. & $\begin{array}{l}\text { Per cent. of total } \\
\text { copper oxide. }\end{array}$ \\
\hline 0 & 0.1268 & $\ldots$ & $\ldots$ & 57.74 \\
\hline Io & 0.2146 & $94.6 \mathrm{r}$ & 0.1275 & 97.72 \\
\hline 20 & 0.2186 & 98.93 & 0.1033 & 99.55 \\
\hline 30 & 0.2170 & 97.05 & $\ldots$. & 98.82 \\
\hline 45 & $0.215^{6}$ & 95.39 & $\ldots$ & 9 S.I 7 \\
\hline 60 & $0.218 \mathrm{I}$ & 98.23 & $\ldots \ldots$ & $99 \cdot 32$ \\
\hline I 20 & 0.2160 & 95.84 & $\ldots$ & 98.36 \\
\hline (calc.) & 0.2196 & $100 . \infty$ & $\ldots$ & 100.00 \\
\hline 0 & 0.1268 & $\ldots \ldots$ & $\ldots \ldots$ & 57.74 \\
\hline $31 / 2$ & 0.1909 & 69.07 & 0.146 & 86.93 \\
\hline $51 / 2$ & 0.2040 & 83.18 & 0.1416 & 92.90 \\
\hline $7 \mathrm{I} / 2$ & $0.21 I_{4}$ & 91.15 & o. 1407 & 96.27 \\
\hline (calc.) & 0.2196 & 100.00 & $\ldots \ldots$ & 100.00 \\
\hline
\end{tabular}

The results with a 2 per cent. solution are the mean of two closely concordant series of determinations.

If we assume 0.143 as the constant, a hydrolysis of 99.5 per cent. should, theoretically, be obtained in 16.1 minutes. The hydrolysis is approximately three times as rapid as at $100^{\circ}$. The rate of hydrolysis approximates that required for a normal mass reaction only for about eight to ten minutes. The maximum amount of copper is obtained in from twenty to thirty minutes.

Hydrolysis of Dextrin.-Six series of determinations of the rate of hydrolysis of dextrin were made. The dextrin was prepared by making a moderately thick, homogeneous, and nearly transparent, starch paste. This was then treated with malt at a temperature of $60^{\circ}-62^{\circ}$ for from fifteen to twenty minutes. The solution was filtered, concentrated on a water-bath in a partial vacuum and the dextrin precipitated by adding alcohol (sp. gr. 0.83 ). The precipitated gum was dissolved in water and reprecipitated several times and after the last precipitation it was rendered pulverulent by treatment with strong alcohol. It was then thoroughly dried in a vacuum desiccator over sulphuric acid. The dextrin still retained 1.6 per cent. of maltose, but the results were corrected for this on the basis of the rate of hydrolysis of the maltose as previously determined. It was assumed, in calculating the results, that 9 parts of anhydrous dextrin should give Io parts of glucose.

The average for the six series of determinations was as follows: 


$\begin{array}{rccc}\text { Time. } & \text { Copper. } & \text { Per cent. bydrolyzed. } & \text { K. } \\ 6 & 0.0560 & 28.29 & 0.0242 \\ \text { I I } & 0.0892 & 45.14 & 0.0237 \\ \text { I6 } & 0.1155 & 58.45 & 0.0238 \\ \text { 2I } & 0.1349 & 68.32 & 0.0236 \\ 3 \text { I } & 0.1570 & 79.45 & 0.0221 \\ \text { 6I } & 0.1791 & 90.64 & 0.0167 \\ \text { I2 I } & 0.1875 & 94.84 & 0.0114 \\ \text { (calc.) } & 0.1976 & 100.00 & \end{array}$

If we assume the constant as 0.023 , one hour and forty minutes should, theoretically, be required for a conversion of 99.5 per cent.

The rate of hydrolysis is approximately one-half that for maltose. After thirty minutes the rate of hydrolysis falls below that required by the constant of the earlier periods, and it appears improbable that complete hydrolysis could be obtained by prolonged heating. The heating was not continued long enough to establish this point, however.

The Hydrolysis of the Mixture of Starch and Dextrin Resulting from the Action of Malt on Starch.-A sample of commercial maize starch was used for the following experiments. This was analyzed and gave:

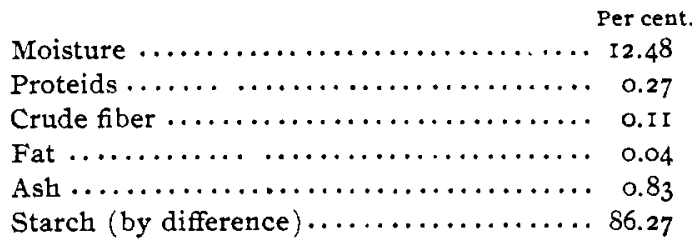

Several combustions were made and these gave, calculated for the anhydrous, ash-free material:

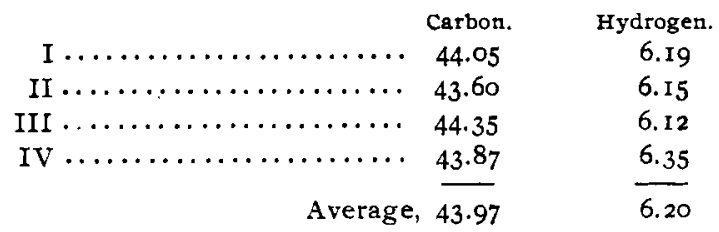

The ash was largely an alkali carbonate. To determine the amount of carbon in it 5.767 grams of the starch were burned, giving 0.0472 gram of ash. After treatment with nitric acid and drying at $175^{\circ}-200^{\circ}$, this increased in weight by $0.0296 \mathrm{gram}$, from which it is calculated that the ash contained 0.0056 gram 
carbon. This would be 0.1 I per cent. of the anhydrous starch, giving a total of 44.08 per cent. carbon in the anhydrous, ash-free material. If we assume the proteids as containing 53 per cent. and the fat 77 per cent. of carbon, the per cent. of carbon in the pure starch is 44.05 .

\begin{tabular}{|c|c|c|c|}
\hline & $\begin{array}{l}\text { Calculated for } \\
\qquad\left(\mathrm{C}_{6} \mathrm{H}_{10} \mathrm{O}_{5}\right)_{n} \text {. }\end{array}$ & $\begin{array}{l}\text { Calculated for } \\
\mathrm{C}_{30} \mathrm{H}_{62} \mathrm{O}_{31}{ }^{\circ}\end{array}$ & Found \\
\hline$\ldots \ldots \ldots$ & $\begin{array}{l}\text {. } 44.44\end{array}$ & 4.3 .64 & 44.05 \\
\hline Hydrogen ............ & 6.23 & 6.33 & 6.20 \\
\hline
\end{tabular}

The results evidently agree much better with the commonly accepted formula than with Nägeli's formula.

Rate of Hydrolysis in $0.5 \mathrm{Per}$ Cent. Solution.-About I gram of the starch was weighed into a flask, treated with a little water and mixed well. About $100 \mathrm{cc}$. of water were then added and the whole was heated to boiling on an asbestos plate. The boiling was continued with constant stirring for about twenty minutes. The flask was then immersed in a bath kept at $55^{\circ}-60^{\circ}$, Io cc. of malt extract were added, and the flask and contents kept at that temperature for from thirty to sixty minutes. The malt extract was prepared by digesting Io grams of ground malt with $100 \mathrm{cc}$. of water for an hour and filtering. The contents of the flask were then boiled for five minutes, cooled, the volumes made up to 200 $\mathrm{cc}$, and $20 \mathrm{cc}$. of hydrochloric acid (25 per cent.) added. The rate of hydrolysis was then determined in the manner which has been described for maltose. The original reducing power of the extract of malt used was, of course, determined, and also its reducing power after hydrolysis with hydrochloric acid and the appropriate corrections were made.

Four series were made with periods of naught, five, ten, fifteen, twenty and thirty minutes, and four series with naught and twenty minutes, and one, two, three and four hours. To save space, only the constants and the averages will be given, and all will be combined in a single table.

1 Nägeli's formula: Ztschr, anal. Chem., 17, 232. 
Hydrolysis of Starch Products. 0.5 Per cent. Solution.

\begin{tabular}{|c|c|c|c|c|c|c|c|}
\hline \multirow{3}{*}{$\begin{array}{c}\text { Time. } \\
\text { Minutes. } \\
o\end{array}$} & \multicolumn{4}{|c|}{ Constaxits. } & \multirow{2}{*}{$\begin{array}{c}\text { Average } \\
\text { per cent. } \\
\text { hydrolyzed. }\end{array}$} & & \multirow{2}{*}{$\begin{array}{l}\text { Average per } \\
\text { cent. total co } \\
\mathbf{K} \text {. per oxide. }\end{array}$} \\
\hline & I. & 2. & 3. & 4. & & Average & \\
\hline & $\ldots \ldots$ & $\ldots \ldots$ & $\ldots \ldots$ & $\ldots \ldots$ & 0.0 & $\ldots \ldots$ & 43.59 \\
\hline 5 & 0.0527 & $0.049 \mathrm{I}$ & $0.054^{\circ}$ & 0.0487 & 44.46 & $0.05 \mathrm{II}$ & 68.75 \\
\hline 10 & $0.043^{\circ}$ & $0.04 \mathrm{~T} 2$ & 0.0369 & 0.0405 & 60.43 & 0.0404 & 78.32 \\
\hline I5 & 0.0346 & 0.0355 & 0.0338 & 0.0362 & 70.15 & 0.0350 & 83.22 \\
\hline 20 & 0.0307 & 0.0323 & 0.0296 & 0.0314 & 75.96 & 0.0310 & 86.44 \\
\hline $\begin{array}{l}30 \\
\text { Hours. }\end{array}$ & $\cdots$ & . & · & 0.0265 & 83.99 & 0.0265 & $91 . \infty$ \\
\hline I & 0.0204 & $0.022 \mathrm{I}$ & 0.0183 & $\ldots$ & 93.76 & 0.0203 & 96.40 \\
\hline 2 & $\cdots$ & $\ldots$ & $\ldots$ & $\ldots$ & 91.86 & $\ldots$ & $95 \cdot 3 \mathrm{I}$ \\
\hline 3 & $\cdots$ & $\ldots \cdot$ & $\cdots \cdots$ & $\ldots \ldots$ & 91.40 & $\cdots$ & 95.00 \\
\hline 4 & $\cdots$ & $\ldots$ & $\ldots$ & $\ldots \ldots$ & 90.32 & $\ldots$ & 94.41 \\
\hline
\end{tabular}

Rate of Hydrolysis in 2 Per Cent. Solution.-Two series were made, in which the concentration of the starch was four times as great, with the following results:

\begin{tabular}{|c|c|c|c|c|}
\hline \multirow{2}{*}{$\begin{array}{c}\text { Time. } \\
\text { Minutes. }\end{array}$} & \multicolumn{2}{|c|}{ Per cent. hydrolyzed. } & \multirow[b]{2}{*}{ Average $\mathrm{K}$. } & \multirow{2}{*}{$\begin{array}{l}\text { Average per } \\
\text { cent. tota1 } \\
\text { copper oxide. }\end{array}$} \\
\hline & I. & 2. & & \\
\hline$\circ$ & 0.0 & 0.0 & $\cdots \cdots$ & 45.62 \\
\hline IO & 52.27 & 51.17 & 0.0316 & 73.76 \\
\hline 20 & 73.35 & 74.42 & 0.0292 & 85.80 \\
\hline $\begin{array}{l}30 \\
\text { Hours. }\end{array}$ & 86. I0 & 86.75 & 0.0289 & 92.61 \\
\hline I & 94.73 & 94.76 & 0.0213 & 97.14 \\
\hline 2 & $94.5^{8}$ & 96.15 & $\cdots \cdots$ & 97.47 \\
\hline 3 & 87.04 & 90.45 & $\ldots \ldots$ & 93.90 \\
\hline
\end{tabular}

Hydrolysis in 2 Per Cent. Solution at $110.8^{\circ}$. - One series of determinations was made in boiling toluene, as has been described for maltose, with the following results:

$\begin{array}{cccc}\begin{array}{c}\text { Time. } \\ \text { Minutes. }\end{array} & \begin{array}{c}\text { Percent. } \\ \text { hydrolyzed. }\end{array} & \text { K. } & \begin{array}{c}\text { Per cent. of total } \\ \text { copper oxide. }\end{array} \\ 0 & \ldots \ldots & \ldots . . & 45.78 \\ 3 \mathrm{I} / 2 & 6 \mathrm{I} .20 & 0.1 \mathrm{I} 8 & 79.04 \\ 5 \mathrm{I} / 2 & 76.32 & 0.1 \mathrm{I} 3 & 87.15 \\ 7 \mathrm{I} / 2 & 84.00 & 0.106 & 9 \mathrm{I} .3 \mathrm{I} \\ 20 & 95.40 & 0.067 & 97.65 \\ 30 & 97.5 \mathrm{I} & 0.053 & 98.68 \\ 60 & 94.55 & \ldots \ldots & 97.12 \\ 120 & 86.76 & \ldots \ldots & 93.00\end{array}$

In general, the results obtained with the mixture of maltose and dextrin, which is formed by the action of malt upon starch, agree closely with those obtained before by the hydrolysis of maltose and dextrin separately. 
Direct Hydrolysis of Starch with Hydrochloric Acid.-This was not directly connected with the remainder of the work, but one series of determinations was. made which may be of enough interest to record. The starch, 1.2976 grams, was boiled with I $50 \mathrm{cc}$. of water for a half hour, the emulsion cooled, made to $250 \mathrm{cc}$, and $25 \mathrm{cc}$. of hydrochloric acid $(25$ per cent.) added. The hydrolysis was then followed at $100^{\circ}$, as in the other cases.

$\begin{array}{cccc}\begin{array}{c}\text { Time. } \\ \text { Minutes. }\end{array} & \text { Copper oxide. } & \begin{array}{c}\text { Per cent. } \\ \text { hydrolyzed. }\end{array} & \mathrm{K} . \\ 5 & 0.0742 & 30.5 \mathrm{I} & 0.0316 \\ \text { IO } & 0.1254 & 51.56 & 0.0315 \\ \text { I5 } & 0.1596 & 65.62 & 0.0309 \\ 20 & 0.1830 & 75.25 & 0.0303 \\ 30 & 0.2150 & 88.40 & 0.0312 \\ \text { Hours. } & & & \\ \text { I } & 0.2358 & 96.96 & 0.0253 \\ 2 & 0.2376 & 97.70 & 0.0068 \\ 4 & 0.2384 & 98.02 & 0.0035 \\ \text { (calc.) } & 0.2432 & 100.00 & \cdots\end{array}$

CONCLUSIONS.

I. In none of these cases, which we have studied, does the hydrolysis proceed towards its conclusion as a normal mass reaction. In each case the reaction follows the law approximately for a short time and then becomes much slower than would accord with its earlier rate. Sigmond, ${ }^{1}$ in following the reaction at $74^{\circ}$, reached a different conclusion, but he carried the hydrolysis to only 73.5 per cent., at most, and depended exclusively on the rotary power in his determinations. It would be interesting to determine whether a more complete hydrolysis than we have obtained at $100^{\circ}$ could be secured at the lower temperature.

2. While glucose itself is scarcely affected in its reducing power by heating with a 2.5 per cent. solution of hydrochloric acid, the products formed by the hydrolysis of maltose are of such a nature that a maximum reducing power is reached after about one hour at $100^{\circ}$, or after twenty or thirty minutes at $\mathrm{III}^{\circ}$. Further heating causes a quite considerable decrease in the reducing power. The maximum reducing power corresponds to a hydrolysis of 96 to 98 per cent. This reducing power is 98 to 99 per cent. of the reducing power which would be attained on

\footnotetext{
1 Ztschr. phys. Chem., 27, 385 .
} 
complete hydrolysis. This agrees closely with the results obtained by Meissl. ${ }^{1}$

There is a pretty clear indication that the hydrolysis is more complete in a 2 or 4 per cent. solution than in the 0.5 per cent. solution. There is also, apparently, a slight advantage in using a temperature of $I I I^{\circ}$ rather than $100^{\circ}$.

3. The rate of hydrolysis for dextrin is about one-half that for maltose. Dextrin also shows the same retardation in the reaction which was found with maltose at $100^{\circ}$. The hydrolysis reaches 90 per cent. in one hour. For a normal reaction of the first order, it should reach 99 per cent. in two hours, but, instead of this, there is a hydrolysis of a little less than 95 per cent.

4. The reducing power of the products obtained in our ex. periments by the action of extract of malt upon starch indicates a composition of 74 to 78 per cent. of maltose and 26 to 22 per cent. of dextrin. Such a mixture, from the results recorded above, should give, after one hour at $100^{\circ}$, about 96 per cent. of the copper oxide which would correspond to a complete hydrolysis. The amount actually found is slightly greater, being 96.4 per cent. for the 0.5 per cent. solution and 97.1 per cent. for the 2 per cent. solution. While a continuance of the heating beyond one hour increases the hydrolysis of the dextrin, the decrease in the reducing power of the hydrolysis products of the maltose nearly or quite neutralizes the effect at the end of the second hour so that, practically, the maximum reducing effect is reached, at $100^{\circ}$, in about one hour's time.

5. By the direct treatment of maize starch with hydrochloric acid (2.5 per cent.) in a 0.5 per cent. solution we have obtained a hydrolysis of 97 per cent. in one hour and of 98 per cent. in four hours. It is noticeable that in this case the reducing power did not decrease. Solomon ${ }^{2}$ obtained a complete hydrolysis of potato starch in three hours under similar conditions. Beilstein ${ }^{3}$ states, on Solomon's authority, that rice starch gives nearly 4 per cent. less glucose than does potato starch under these conditions.

6. For the determination of starch we would recommend that, after filtration, Io per cent. by volume of hydrochloric acid (sp.

1 J.prakt. Chem., (2), $25,124$.

2 Ibid., (2), $25,355$.

"Handbuch d. org. Chem"., Vol. 1, p. 1084. 
gr. I.I25) should be added to the solution resulting from the action of extract of malt on the material under examination. After heating for one hour in a flask immersed in a boiling waterbath, making allowance for the time required for the solution to attain the temperature of the bath, the solution is cooled, enough sodium hydroxide is added to neutralize 90 per cent. of the hydrochloric acid used, the solution made up to a definite volume, filtered on a dry filter, if necessary, and the reducing power determined by Fehling's solution. Ioo parts of glucose found in this manner represent 93 parts of starch in the original material. The chemist should determine for himself, with pure glucose, the ratio between glucose and copper oride or copper for the solutions and method which he uses.

\section{THE BEHAVIOR OF URIC ACID IN THE URINE AND THE EFFECT OF ALKALIES ON THE SOLUBILITY OF URIC ACID IN THE URINE.'}

By Francis H. MCCrudien.

Received December 30, 2903.

WHEN urine cools, a precipitate of uric acid, or sodium urate, or a mixture of the two, very frequently occurs. But not all the uric acid precipitates. The cause for this precipitation, and the factors which determine how much uric acid shall remain in solution after equilibritum is reached, have always been points of controversy. The subject is one of very great importance in medicine. Theories of gout and the uric acid diathesis and methods of treatment in these diseases have often been evolved from a study of the behavior of the uric acid in the urine.

At first the precipitation was thought to be due to a simple decrease in solubility on cooling, and that the greater the quantity of uric acid present the larger the precipitate. Later it was supposed that an increase in the acidity of the urine takes place on cooling, changing the sodium urate to insoluble uric acid. Again, the alkaline sodium phosphate was supposed to play the rôle of a uric acid solvent. The quantity of alkaline sodium phosphate present, the ratio between the alkaline and the acid sodium phosphate, the quantity of salts present, the amount of coloring-mat-

1 Read at the St. Louis Meeting of the American Chemical Society. 